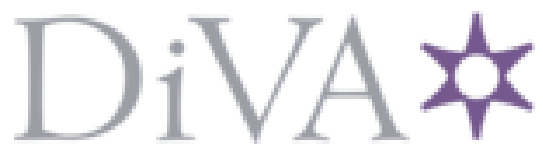

http://www.diva-portal.org

This is the published version of a paper published in .

Citation for the original published paper (version of record):

Drake, H., Ivarsson, M., Heim, C. (2020)

Tracking the Deep Biosphere through Time

Geosciences, 10(11): 461

https://doi.org/10.3390/geosciences10110461

Access to the published version may require subscription.

N.B. When citing this work, cite the original published paper.

Permanent link to this version:

http://urn.kb.se/resolve?urn=urn:nbn:se:Inu:diva-98969 


\title{
Tracking the Deep Biosphere through Time
}

\author{
Henrik Drake ${ }^{1, * \mathbb{D}}$, Magnus Ivarsson ${ }^{2}$ and Christine Heim ${ }^{3}$ (i) \\ 1 Department of Biology and Environmental Science, Linnaeus University, 39182 Kalmar, Sweden \\ 2 Department of Paleobiology, Swedish Museum of Natural History, Box 50007, 10405 Stockholm, Sweden; \\ magnus.ivarsson@nrm.se \\ 3 Institute for Geology and Mineralogy, University of Cologne, 50674 Cologne, Germany; \\ christine.heim@uni-koeln.de \\ * Correspondence: henrik.drake@Inu.se
}

Received: 6 November 2020; Accepted: 13 November 2020; Published: 15 November 2020

check for updates

\begin{abstract}
The oceanic and continental lithosphere constitutes Earth's largest microbial habitat, yet it is scarcely investigated and not well understood. The physical and chemical properties here are distinctly different from the overlaying soils and the hydrosphere, which greatly impact the microbial communities and associated geobiological and geochemical processes. Fluid-rock interactions are key processes for microbial colonization and persistence in a nutrient-poor and extreme environment. Investigations during recent years have spotted microbial processes, stable isotope variations, and species that are unique to the subsurface crust. Recent advances in geochronology have enabled the direct dating of minerals formed in response to microbial activity, which in turn have led to an increased understanding of the evolution of the deep biosphere in (deep) time. Similarly, the preservation of isotopic signatures, as well as organic compounds within fossilized micro-colonies or related mineral assemblages in voids, cements, and fractures/veins in the upper crust, provides an archive that can be tapped for knowledge about ancient microbial activity, including both prokaryotic and eukaryotic life. This knowledge sheds light on how lifeforms have evolved in the energy-poor subsurface, but also contributes to the understanding of the boundaries of life on Earth, of early life when the surface was not habitable, and of the preservation of signatures of ancient life, which may have astrobiological implications. The Special Issue "Tracking the Deep Biosphere through Time" presents a collection of scientific contributions that provide a sample of forefront research in this field. The contributions involve a range of case studies of deep ancient life in continental and oceanic settings, of microbial diversity in sub-seafloor environments, of isolation of calcifying bacteria as well as reviews of clay mineralization of fungal biofilms and of the carbon isotope records of the deep biosphere.
\end{abstract}

Keywords: deep biosphere; geobiology; deep time; geochronology; microorganisms; evolution

\section{Introduction}

The deep biosphere is estimated to represent a significant portion of all live biomass on Earth [1,2]. Its realm ranges downwards into sediments, sedimentary and igneous rock [3-5]. The microbial communities here include mainly prokaryotes (bacteria and archaea) [6] but findings of eukaryotes such as active and fossilized fungi [7-15], as well as live and indigenous nematodes [16], have also been reported at great depth. The strict energy limitation, absence of sunlight and dominantly anoxic conditions of these systems make them different to other ecosystems on Earth in terms of metabolic flexibility and recycling [4,17-22]. The deep biosphere is the second largest reservoir of live biomass today, only surpassed by land plants. However, it has been put forward that most of Earth's live biomass $(\sim 80 \%)$ was to be found in the deep biosphere prior to plant colonization of land [23]. The deep 
biosphere may thus have played a crucial role in the early evolution of both prokaryotes and eukaryotes, and dominated life on Earth for most of the planet's history. Yet, in addition to being an understudied environment in general when it comes to active communities, research on the deep time perspective of the deep biosphere has been particularly neglected. Microbiological and geobiological studies of the deep biosphere have, however, been the subject of increased interest in the last decade $[10,18,24,25]$. Similarly, the environmental conditions of these deep and more or less isolated settings have gained more attention lately [26]. By initiating the Special Issue, "Tracking the Deep Biosphere through Time", we aim to gather a collection of scientific contributions that provide a sample of forefront research in this emerging field of research. The contributions range from detection of ancient biosignatures in continental and oceanic settings, to microbial diversity in sub-seafloor environments and to isolation of calcifying bacteria. Two articles timely review clay mineral fossilization of fungal biofilms and the carbon isotope records of the deep biosphere.

\section{An Overview of the Special Issue and the Contributions}

A total of seven articles were published within this Special Issue; of which, five are research articles and two are reviews. A short summary for each contribution is given below.

Tillberg et al. [27] re-evaluate previously described fungal fossils [13] from the Lockne meteorite crater (age: $458 \mathrm{Ma}$ ), Sweden, by providing new in-situ $\mathrm{Rb} / \mathrm{Sr}$ geochronological constraints of secondary calcite-albite-feldspar mineralization in veins and cavities of the impact structure, together with the fungal fossils. This new geochronological technique has shown to be feasible for dating complex discretely zoned mineral assemblages in fractured rock [28-32] and yielded a $357 \pm 7$ Ma age for the Lockne mineral assemblage. The study concludes that fungal colonization took place at least $100 \mathrm{Myr}$ after the impact event, thus long after the impact-induced hydrothermal activity ceased. Microscale stable isotope data of ${ }^{13} \mathrm{C}$-enriched calcite are also presented and reveled that microbial methanogenesis had occurred within the fracture system as well. Thus, the Lockne fungal fossils are not related to the impact event but represent later colonization of fractures formed by the impact.

In a study from the deep borehole, COSC-1, drilled into the Silurian-Devonian Scandinavian Caledonide mountain range in Central Sweden, Drake et al. [33] present isotopic and geochronological constraints for ancient microbial life in deep fractures and micro-karst formations in the nappe system. Micro-karsts at 122-178 m depth featured several generations of secondary calcite and pyrite growth. The younger of these precipitation phases showed ${ }^{34} S$-depleted $\delta^{34} S_{\text {pyrite }}$ values consistent with microbial sulfate reduction in situ. Laser ablation inductively coupled mass spectrometry carbonate $\mathrm{U}-\mathrm{Pb}$ geochronology [34] was applied to the late stage calcite of this assemblage and gave two separate ages $(9.6 \pm 1.3 \mathrm{Ma}$ and $2.5 \pm 0.2 \mathrm{Ma})$. These ages mark fluid circulation, related bacterial activity and mineral precipitation, following karst formation. The results show that the combined high spatial-resolution stable isotope and geochronology approach is suitable for characterizing paleo-fluid flow in micro-karst in nappe units.

Carlsson et al. [35] describe filamentous fossils interpreted as fungal remains from the Troodos ophiolite (91 Ma), Cyprus. Mineralogy and fluid inclusion studies show that the microorganisms lived in the system while the volcanism-related hydrothermal activity still was active in the seafloor, thus before the crust was emplaced on land. The paper highlights the importance of detailed geochemical investigations associated with descriptions of potential microfossils in the deep subsurface. Reconstructing the past habitats, fluid regimes and geochemical conditions are key in understanding fossilization and addressing biogenicity criteria.

Martino et al. [36] explore the microbial community of the sub-seafloor sediments obtained during IODP (International Ocean Discovery Program) Expedition 334 at Costa Rica Margin. The correlation assessment between microbial taxa (Bacteria, Archaea and Eukaryotes) and environmental chemistry surprisingly diverge despite their geographical proximity, similar lithology and similar pore water chemistry. The major taxonomic lineages identified have also been found in sub-seafloor environments worldwide. Up to now, knowledge about habitat preferences and metabolic specializations is rather 
low regarding this environment and therefore variations in their relative abundance are just partly explained. However, this study also shows that contamination issues for such subsurface drilling projects seem well manageable and therefore should not hinder further necessary research.

Cacchio and Gallo [37] provide a methodical study describing calcium-carbonate precipitation processes in bacterial strains isolated from the rhizosphere. In contrast to bacterial carbonate precipitation in speleothems, the biomineralization potential in rhizosphere soils is understudied. Assessing the carbonate precipitation in the original environment and in enrichment cultures, this is the first study to show the biomineralization ability of the bacterial strains Vibrio tubiashii, Clavibacter agropyri (Corynebacterium), Corynebacterium urealyticum, Sanguibacter suarezii, Sphingomonas sanguinis, and Pseudomonas syringae, which are commonly not related to mineral precipitation. Initial mineral precipitation was induced in direct vicinity of the bacterial cells and thus attributable to the metabolic activity of the cells. Besides presenting well adapted and versatile subsurface organisms, the authors highlight methodical approaches for efficient and cost-optimized microbial community analysis and rapid screenings.

Sallstedt et al. [38] review the current data on clay mineralization by fossil fungal biofilms from oceanic and continental subsurface igneous rock. The aim of the review is to compare the nature of subsurface fungal clays from different igneous settings to evaluate the importance of host rock and ambient redox conditions for clay speciation related to fossilization of microorganisms. Montmorillonite-like smectite is the dominant clay involved in subsurface microbial fossilization, independent of host rock type and geochemical regime. The paper highlights the role of fungal clay authigenesis in the cycling of elements between host rock, ocean and precipitation of secondary minerals.

Meister and Reyes [39] review the carbon isotope record of the sub-seafloor biosphere, which exhibits large carbon-isotope fractionation effects as a result of microbial enzymatic reactions. The review presents a brief and timely overview on carbon isotopes, including microbial fractionation mechanisms, transport effects, preservation in diagenetic carbonate archives, and their implications for the past sub-seafloor biosphere. Particularly large carbon-isotope fractionation linked to methanogenesis and fractionations occurring during this process is a focus of the review. Methane metabolisms in Archaea and Bacteria essentially mediate through the enzymatic Wood-Ljungdahl pathway, but it remains unclear where in the pathway carbon-isotope fractionation occurs. In marine porewaters (and diagenetic carbonates), the highly varying $\mathrm{C}$ isotopic signature of dissolved inorganic carbon and methane reflects different microbial metabolisms [40]. Carbon isotope compositions of diagenetic carbonates may therefore act as biosignatures for ancient deep biosphere conditions.

\section{Summary and Outlook}

As stated in the introduction, the deep biosphere is understudied, particularly in a deep time perspective. With this Special Issue, we have gathered a collection of well-needed additions to take the state of knowledge further, and that we hope can inspire new research on both fossil and active communities in this vast realm.

Author Contributions: H.D., M.I. and C.H. handled the Special Issue and wrote the editorial. All authors have read and agreed to the published version of the manuscript.

Funding: The research projects of the authors of this editorial are funded by Formas (contract 2017-00766 to H.D.) and the Swedish Research Council (contract 2017-05186 to H.D., 2017-04129 to M.I.).

Acknowledgments: We thank the authors contributing to this Special Issue and Daisy Hu at MDPI for handling.

Conflicts of Interest: The authors declare no conflict of interest. 


\section{References}

1. McMahon, S.; Parnell, J. Weighing the deep continental biosphere. FEMS Microbiol. Ecol. 2014, 87, 113-120. [CrossRef]

2. Magnabosco, C.; Lin, L.H.; Dong, H.; Bomberg, M.; Ghiorse, W.; Stan-Lotter, H.; Pedersen, K.; Kieft, T.L.; van Heerden, E.; Onstott, T.C. The biomass and biodiversity of the continental subsurface. Nat. Geosci. 2018, 11, 707-717. [CrossRef]

3. Pedersen, K. Exploration of deep intraterrestial microbial life: Current perspectives. FEMS Microbiol. Lett. 2000, 185, 9-16. [CrossRef] [PubMed]

4. Hoehler, T.M.; Jorgensen, B.B. Microbial life under extreme energy limitation. Nat. Rev. Genet. 2013, 11, 83-94. [CrossRef] [PubMed]

5. D’Hondt, S.; Jørgensen, B.B.; Miller, D.J.; Batzke, A.; Blake, R.; Cragg, B.A.; Cypionka, H.; Dickens, G.R.; Ferdelman, T.; Hinrichs, K.-U.; et al. Distributions of Microbial Activities in Deep Subseafloor Sediments. Science 2004, 306, 2216. [CrossRef]

6. Lopez-Fernandez, M.; Simone, D.; Wu, X.; Soler, L.; Nilsson, E.; Holmfeldt, K.; Lantz, H.; Bertilsson, S.; Dopson, M. Metatranscriptomes Reveal That All Three Domains of Life Are Active but Are Dominated by Bacteria in the Fennoscandian Crystalline Granitic Continental Deep Biosphere. mBio 2018, 9, e01792. [CrossRef]

7. Drake, H.; Ivarsson, M.; Bengtson, S.; Heim, C.; Siljeström, S.; Whitehouse, M.J.; Broman, C.; Belivanova, V.; Åström, M.E. Anaerobic consortia of fungi and sulfate reducing bacteria in deep granite fractures. Nat. Commun. 2017, 8, 55. [CrossRef]

8. Ivarsson, M.; Kilias, S.P.; Broman, C.; Neubeck, A.; Drake, H.; Fru, E.C.; Bengtson, S.; Naden, J.; Detsi, K.; Whitehouse, M.J. Exceptional Preservation of Fungi as H2-Bearing Fluid Inclusions in an Early Quaternary Paleo-Hydrothermal System at Cape Vani, Milos, Greece. Minerals 2019, 9, 749. [CrossRef]

9. Drake, H.; Ivarsson, M. The role of anaerobic fungi in fundamental biogeochemical cycles in the deep biosphere. Fungal Biol. Rev. 2018, 32, 20-25. [CrossRef]

10. Ivarsson, M.; Bengtson, S.; Drake, H.; Francis, W. Fungi in Deep Subsurface Environments. In Advances in Applied Microbiology; Academic Press: London, UK, 2018; Volume 102, pp. 83-116.

11. Bengtson, S.; Rasmussen, B.; Ivarsson, M.; Muhling, J.; Broman, C.; Marone, F.; Stampanoni, M.; Bekker, A. Fungus-like mycelial fossils in 2.4-billion-year-old vesicular basalt. Nat. Ecol. Evol. 2017, 1, 0141. [CrossRef]

12. Ivarsson, M.; Bengtson, S.; Skogby, H.; Lazor, P.; Broman, C.; Belivanova, V.; Marone, F. A Fungal-Prokaryotic Consortium at the Basalt-Zeolite Interface in Subseafloor Igneous Crust. PLoS ONE 2015, 10, e0140106. [CrossRef] [PubMed]

13. Ivarsson, M.; Broman, C.; Sturkell, E.; Ormö, J.; Siljeström, S.; van Zuilen, M.; Bengtson, S. Fungal colonization of an Ordovician impact-induced hydrothermal system. Sci. Rep. 2013, 3, 3487. [CrossRef] [PubMed]

14. Purkamo, L.; Kietäväinen, R.; Miettinen, H.; Sohlberg, E.; Kukkonen, I.; Itävaara, M.; Bomberg, M. Diversity and functionality of archaeal, bacterial and fungal communities in deep Archaean bedrock groundwater. FEMS Microbiol. Ecol. 2018, 94, 94. [CrossRef] [PubMed]

15. Sohlberg, E.; Bomberg, M.; Miettinen, H.; Nyyssönen, M.; Salavirta, H.; Vikman, M.; Itävaara, M. Revealing the unexplored fungal communities in deep groundwater of crystalline bedrock fracture zones in Olkiluoto, Finland. Front. Microbiol. 2015, 6, 573. [CrossRef] [PubMed]

16. Borgonie, G.; García-Moyano, A.; Litthauer, D.; Bert, W.; Bester, A.; van Heerden, E.; Möller, C.; Erasmus, M.; Onstott, T.C. Nematoda from the terrestrial deep subsurface of South Africa. Nature 2011, 474, 79-82. [CrossRef]

17. Mhatre, S.S.; Kaufmann, S.; Marshall, I.P.G.; Obrochta, S.; Andrèn, T.; Jørgensen, B.B.; Lomstein, B.A. Microbial biomass turnover times and clues to cellular protein repair in energy-limited deep Baltic Sea sediments. FEMS Microbiol. Ecol. 2019, 95, 95. [CrossRef]

18. Li, J.; Mara, P.; Schubotz, F.; Sylvan, J.B.; Burgaud, G.; Klein, F.; Beaudoin, D.; Wee, S.Y.; Dick, H.J.B.; Lott, S.; et al. Recycling and metabolic flexibility dictate life in the lower oceanic crust. Nature 2020, 579, 250-255. [CrossRef] 
19. Wu, X.; Holmfeldt, K.; Hubalek, V.; Lundin, D.; Åström, M.; Bertilsson, S.; Dopson, M. Microbial metagenomes from three aquifers in the Fennoscandian shield terrestrial deep biosphere reveal metabolic partitioning among populations. ISME J. 2016, 10, 1192-1203. [CrossRef]

20. Kieft, T.L.; Walters, C.C.; Higgins, M.B.; Mennito, A.S.; Clewett, C.F.M.; Heuer, V.; Pullin, M.J.; Hendrickson, S.; van Heerden, E.; Sherwood Lollar, B.; et al. Dissolved organic matter compositions in 0.6-3.4 km deep fracture waters, Kaapvaal Craton, South Africa. Org. Geochem. 2018, 118, 116-131. [CrossRef]

21. Lau, M.C.Y.; Kieft, T.L.; Kuloyo, O.; Linage-Alvarez, B.; van Heerden, E.; Lindsay, M.R.; Magnabosco, C.; Wang, W.; Wiggins, J.B.; Guo, L.; et al. An oligotrophic deep-subsurface community dependent on syntrophy is dominated by sulfur-driven autotrophic denitrifiers. Proc. Natl. Acad. Sci. USA 2016, 113, E7927-E7936. [CrossRef]

22. Lever, M.A.; Rogers, K.L.; Lloyd, K.G.; Overmann, J.; Schink, B.; Thauer, R.K.; Hoehler, T.M.; Jørgensen, B.B. Life under extreme energy limitation: A synthesis of laboratory- and field-based investigations. FEMS Microbiol. Rev. 2015, 39, 688-728. [CrossRef] [PubMed]

23. McMahon, S.; Parnell, J. The deep history of Earth's biomass. J. Geol. Soc. 2018, 175, 716. [CrossRef]

24. Ivarsson, M.; Drake, H.; Neubeck, A.; Sallstedt, T.; Bengtson, S.; Roberts, N.M.W.; Rasmussen, B. The fossil record of igneous rock. Earth-Sci. Rev. 2020, 210, 103342. [CrossRef]

25. Inagaki, F.; Hinrichs, K.U.; Kubo, Y.; Bowles, M.W.; Heuer, V.B.; Hong, W.L.; Hoshino, T.; Ijiri, A.; Imachi, H.; Ito, M.; et al. Exploring deep microbial life in coal-bearing sediment down to $\sim 2.5 \mathrm{~km}$ below the ocean floor. Science 2015, 349, 420. [CrossRef] [PubMed]

26. Lollar, G.S.; Warr, O.; Telling, J.; Osburn, M.R.; Lollar, B.S. 'Follow the Water': Hydrogeochemical Constraints on Microbial Investigations $2.4 \mathrm{~km}$ Below Surface at the Kidd Creek Deep Fluid and Deep Life Observatory. Geomicrobiol. J. 2019, 36, 859-872. [CrossRef]

27. Tillberg, M.; Ivarsson, M.; Drake, H.; Whitehouse, J.M.; Kooijman, E.; Schmitt, M. Re-Evaluating the Age of Deep Biosphere Fossils in the Lockne Impact Structure. Geosciences 2019, 9, 202. [CrossRef]

28. Tillberg, M.; Drake, H.; Zack, T.; Kooijman, E.; Whitehouse, M.J.; Åström, M.E. In situ Rb-Sr dating of slickenfibres in deep crystalline basement faults. Sci. Rep. 2020, 10, 562. [CrossRef]

29. Tillberg, M.; Maskenskaya, O.M.; Drake, H.; Hogmalm, J.K.; Broman, C.; Fallick, A.E.; Åström, M.E. Fractionation of Rare Earth Elements in Greisen and Hydrothermal Veins Related to A-Type Magmatism. Geofluids 2019, 2019, 20. [CrossRef]

30. Drake, H.; Whitehouse, M.J.; Heim, C.; Reiners, P.W.; Tillberg, M.; Hogmalm, K.J.; Dopson, M.; Broman, C.; Åström, M.E. Unprecedented ${ }^{34}$ S-enrichment of pyrite formed following microbial sulfate reduction in fractured crystalline rocks. Geobiology 2018, 16, 556-574. [CrossRef]

31. Drake, H.; Ivarsson, M.; Tillberg, M.; Whitehouse, M.; Kooijman, E. Ancient Microbial Activity in Deep Hydraulically Conductive Fracture Zones within the Forsmark Target Area for Geological Nuclear Waste Disposal, Sweden. Geosciences 2018, 8, 211. [CrossRef]

32. Drake, H.; Heim, C.; Roberts, N.M.W.; Zack, T.; Tillberg, M.; Broman, C.; Ivarsson, M.; Whitehouse, M.J.; Åström, M.E. Isotopic evidence for microbial production and consumption of methane in the upper continental crust throughout the Phanerozoic eon. Earth Planet. Sci. Lett. 2017, 470, 108-118. [CrossRef]

33. Drake, H.; Roberts, M.W.N.; Whitehouse, J.M. Geochronology and Stable Isotope Analysis of Fracture-Fill and Karst Mineralization Reveal Sub-Surface Paleo-Fluid Flow and Microbial Activity of the COSC-1 Borehole, Scandinavian Caledonides. Geosciences 2020, 10, 56. [CrossRef]

34. Roberts, N.M.W.; Drost, K.; Horstwood, M.S.A.; Condon, D.J.; Chew, D.; Drake, H.; Milodowski, A.E.; McLean, N.M.; Smye, A.J.; Walker, R.J.; et al. Laser ablation inductively coupled plasma mass spectrometry (LA-ICP-MS) U-Pb carbonate geochronology: Strategies, progress, and limitations. Geochronology 2020, 2, 33-61. [CrossRef]

35. Carlsson, D.-T.; Ivarsson, M.; Neubeck, A. Fossilized Endolithic Microorganisms in Pillow Lavas from the Troodos Ophiolite, Cyprus. Geosciences 2019, 9, 456. [CrossRef]

36. Martino, A.; Rhodes, M.E.; León-Zayas, R.; Valente, I.E.; Biddle, J.F.; House, C.H. Microbial Diversity in Sub-Seafloor Sediments from the Costa Rica Margin. Geosciences 2019, 9, 218. [CrossRef]

37. Cacchio, P.; Del Gallo, M. A Novel Approach to Isolation and Screening of Calcifying Bacteria for Biotechnological Applications. Geosciences 2019, 9, 479. [CrossRef] 
38. Sallstedt, T.; Ivarsson, M.; Drake, H.; Skogby, H. Instant Attraction: Clay Authigenesis in Fossil Fungal Biofilms. Geosciences 2019, 9, 369. [CrossRef]

39. Meister, P.; Reyes, C. The Carbon-Isotope Record of the Sub-Seafloor Biosphere. Geosciences 2019, 9, 507. [CrossRef]

40. Meister, P.; Liu, B.; Khalili, A.; Böttcher, M.E.; Jørgensen, B.B. Factors controlling the carbon isotope composition of dissolved inorganic carbon and methane in marine porewater: An evaluation by reaction-transport modelling. J. Mar. Syst. 2019, 200, 103227. [CrossRef]

Publisher's Note: MDPI stays neutral with regard to jurisdictional claims in published maps and institutional affiliations.

(C) 2020 by the authors. Licensee MDPI, Basel, Switzerland. This article is an open access article distributed under the terms and conditions of the Creative Commons Attribution (CC BY) license (http://creativecommons.org/licenses/by/4.0/). 